\title{
国立試験研究機関における環境保全研究の動向
}

\section{1. 環境保全研究の推進}

環境保全研究の効果的な推進を図るためには，科学 技術の支えが不可欠である。一方, 環境保全に関する 科学技術の分野は極めて広範であるため, 理工学, 医 学, 農学等の自然科学の領域ばかりでなく, 社会学, 経済学などの人文科学等の多くの専門分野の参加之協 力が必要となる場合が多い.

環境保全に係る科学技術研究には, 大気污染・水質 污濁物質の排出抑制, 騒音・振動の低減, 污染の計測 等公害防止技術の開発に関する分野, 環境污染か人や 動植物に与える影響をは握評価し, 望ましい環境の質 を明らかにする分野並びに各種污染物質の自然生態系 の中での挙動及び自然の有する浄化機能等環境污染入 カニズムの解明に関する分野などがある。さらに, 最 近は効果的な環境管理システムや開発等に伴う環境影 響の事前評価システムの開発などの分野が重要となっ てきている. これらの研究は現在, 国, 地方公共団体 及び民間に扔いて幅広く進められているが，国におい ては, 污染影響のは握, 污染メカニズムの解明などに 関する基礎科学的な研究をはじめ, 各種基準の設定な ど国の施策推進の基礎となる調查研究を実施するとと もに，公害防止技術についても，開発評価等の基礎的 研究を重点的に行っている.

国は,乙れらの研究を進めるに当たっては, 関連す
環境庁企画調整局研究調整課

る科学技術の分野が広範で, 研究分野が相互、密接に 関連し合っていることから関係する研究機関及び研究 者の緊密な連携を図っていく必要がある，てのため, 環境庁においては，環境庁設置法に基づき，関係行政 機関の公害の防止等に関する経費の見積り方針の調整 を行うとともに, 各省庁の試験研究機関の公害の防止 等に関する経費及び各省訮の公害の防止等に関する武 験研究委託費を一括計上し 環境保全研究の総合的な 推進を図っている (表 1 参照).

試験研究の総合的な推進を図るほか, 緊急事案の発 生時に機動的に対処するため, 環境保全総合調查研究 促進調整費による調査研究を実施している.

また, 所管行政の推進上の重要な課題である各種の 規制基準の設定, 各種污染物質の計測技術等に関し, 必要な調査研究を地方公共甩体, 民間機関等の協力の 下に推進している.

さらに, 国立公害研究所及び国立水俣病研究センター に沶いては, 公害の防止, 水俣病等に関する試験研究, 調査研究を行っているが, 以下, 国立機関の公害防止 等試験研究及び国立公害研究所の概要について述べる.

\section{2. 国立機関の公害防止等試験研究}

\section{1 概 要}

国立機関の公害防止等に係る試験研究費として昭和 56 年度に環境庁に一括計上されたものは, 117 テーマ,

表 1 昭和 56 年度調查研究費一覧

\begin{tabular}{|c|c|c|c|}
\hline 項 & 昭和 55 年度当初予算額 & 昭和 56 年度予算額 & 比較増 $\triangle$ 減 \\
\hline 1. 国立機関公害防止等試験研究費 & $3,248,443^{\text {干円 }}$ & $3,248,443^{\text {f円 }}$ & $0^{\mp \mathrm{P}}$ \\
\hline 2. 環境保全総合調査研究促進調整費 & 232,470 & 209,220 & $\triangle 23,250$ \\
\hline 3. 公害防止等調查研究費 & 977,679 & 962,546 & $\triangle 15,133$ \\
\hline 4. 国立公害研究所 & $4,232,702$ & $4,646,112$ & 413,410 \\
\hline 5. 水俣病研究センター & 320,423 & 355,860 & 35,437 \\
\hline
\end{tabular}


32 億 4844 万円（前年度 117 テーマ, 当初予算額 32 億 4844万円) で, 乙れらの試験研究は, 警察庁, 科学技 術庁, 環境庁, 大蔵省, 文部省, 厚生省, 農林水産省, 通商産業省, 運輸省, 郵政省, 労働省及び建設省の 12 省仃に属する56試験研究機関等に打いて, 実施するて ととしている. 一括計上による公害防止等の試験研究 については, 従来から当面する問題のみならず, 長期 的視野に立った対策推進の基礎を確保するよう配慮す るとともに, 試験研究課題間の有機的連携を密にし, その目的指向性を一層強化するため, 関連する試験研 究を総合的に推進する総合研究プロジェクトを編成し, 試験研究の効率化を図っている. また, 公害防止等に 係る試験研究の重要性にかんがみ, 特に, 環境行政上, 関連する試験研究の重点的強化を図る必要がある事項 を年度ごとに定めており, 昭和 56 年度において重点的 強化を四る事項は次のとおりである。

(1) エネルギーの転換にともなう環境污染防止対策を 推進するための研究

（2）水質污濁発生源における防除技術の開発，赤潮発 生機構の解明, 水域生態系の物質循環機構の解明等 水域の富栄養化等防止対策を推進す万ための研究

(3) 污染物質の鲯境中における挙動, 牛体及び牛態系 に及ばす影響のは握等污染物質の慢性影響の解明に 資するための研究

(4) 大気中における光化学反応機構の解明, 辬素酸化 物及び炭化水素排出抑制技術の開発等光化学才キシ ダント及び窒素酸化物対策の促進を図るための研究

(5) 自動車, 航空機, 工作機械等に上る騒音, 振動及 び橋梁その他による低周波空気振動の発生機構の解 明, 人体に対する影響の解明等騒音, 振動の防止対 策の促進を図るための研究

（6）都市における環境要因のは握，解明並びに快適な 都市環境の形成及び保全に資するための研究

(7) 污染物質, 開発行為等の自然環境に及ぼす影響の 解明並びに自然環境の管理及び保全に関する技術の 開発のための研究

(8) 廃棄物の新処理体系及び再利用技術の開発その他 廃棄物対策の促進を図るための研究

(9) 公害防止に関する迅速的確な測定技術の確立並び に環境污染に対する広域監視測定技術の高度化及び 自動化を図るための研究

\section{2 総合研究プロジェクトの推進}

昭和 56 年度に推進する総合研究プロジェクト数は 10 であり, その内容は次のとおりである (表 2 , 表 3 参照).

\subsection{1 光化学スモッグ等都市型大気複合污染防止に 関する総合研究}

各種の固定発散源や移動発散源から排忠される一次 污染物質である窒素酸化物や炭化水素などは，大気中 で光化学反応を起こして複雑な二次污染物質を生成 する.とのような光化学スモッグ等都㳦型大気複合汇染 の防止対策の確立に資するため，乙の総合研究に扔い ては, 各種の発生源からの大気污染物質排出防止技術 の開発, 光化学反応機構の解明, 大気汇染物所の生体 に及ぼす影響の解明，污染予測の解明及び予測手法の 開発などに関する研究について12課題を引き続き実施 するとととしている.

\section{2. $2 \mathrm{PCB}$ 等新污染物質の評価並びに污染防止に 関する総合研究}

PCBなどの難分解性:の化学物質は, 生物濃縮と食 物連鎖等を通じて人体内に取り込まれ，蓄積し，人の 健康に影響を与える淿それがある。また，鉱業等に起 过する重金属による土壌活染，「場排水中の重金風や 船舶からの投棄油による海洋污染も農作物や魚介類等 の食物を通じて人の健康に影響老与えるおそれがある。 この総合研究に抢いては，合成化兴物啠及び重金風在 中心にして，これらの泒染物質の牛態系内に打ける举 動，人体や動物への椇取経路，体内に打りる蓄皘及ひ 排出過程, 人間や動物に対する毒性之影響機構などの 解明に関する研究老推進する。

昭和 56 年度に扮いては，(1) PCB，重金属等の生 体機能に及ぼす影響，(2) 環境汗染化学物質による魚 介類活染及びモニタリング，(3) 化“学物質の安全性評 価法の開発及び人体湫染のモニタリングお式に関する 研究について，6課題を引き続き尖施するほか, 新規 課題として, 「污染レベルを前提とする環境化学物質 の安全性試験に関する研究, 「アミン系及びアザへテ 口環系環境癌原性物質の微量検索法に関する研究|及 び「生物質を指示剂とする環境活染物質の監視システ ムに関する研究」を字施することとしている.

\section{2.3 排水処理の高度化に関する総合研究}

工業の発展と人口の都打集中化に伴い公基用水域に 排计される工場排水及び生活排水は水域の浄化能力を 超え，排水中に含まれる污染物質も多種多様となった。 乙の総合研究に扔いては，污染排出源に対する排水基 準の設定及び監視体制の強化に対応して，食品加工排 水, 下水などの有機性排水を対象とした物理化学的処 理法及び生物化学的処理法並びに各種工場排水からの 重金属含有排水を対象とした物理化学的処理法など, 
表 2 総合研究プロジェクト総括表

(単位: 千円)

\begin{tabular}{|c|c|c|c|c|}
\hline 総合研究プロジェクト名 & 関 係 & 課題数 & 前年度予算額 & $\begin{array}{l}\text { 昭和 } 56 \text { 年度 } \\
\text { 要 求 額 }\end{array}$ \\
\hline $\begin{array}{l}\text { 1. 光化学スモッグ等都市型大気複合 } \\
\text { 污染防止に関する総合研究 }\end{array}$ & $\begin{array}{l}\text { 科学技術庁, 厚生省, 通商産業 } \\
\text { 省, 運輸省 }\end{array}$ & 12 & 505,201 & 479,753 \\
\hline $\begin{array}{l}\text { 2. } \mathrm{PCB} \text { 等新污染物質の評価並びに } \\
\text { 污染防止に関する総研究 }\end{array}$ & 厚生省 & $\begin{array}{c}8 \\
(1)\end{array}$ & $\begin{array}{c}92,430 \\
(15,482)\end{array}$ & $\begin{array}{l}113,925 \\
(20,571)\end{array}$ \\
\hline $\begin{array}{l}\text { 3. 排水処理の高度化に関する総合 } \\
\text { 究 }\end{array}$ & $\begin{array}{l}\text { 科学技術序, 大蔵省, 厚生省, } \\
\text { 商産業省, 建設省 }\end{array}$ & 17 & 447,686 & 520,860 \\
\hline $\begin{array}{l}\text { 4. 瀬戸内海等沿岸海域の污染防止に } \\
\text { 関合研究 }\end{array}$ & 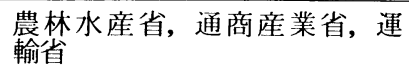 & 13 & $\begin{array}{l}655,719 \\
(50,916)\end{array}$ & 637,407 \\
\hline $\begin{array}{l}\text { 5. 廃棄物の処理と資源化技術に関す } \\
\text { る総合研究 }\end{array}$ & $\begin{array}{l}\text { 厚生省, 農林水産省, 通商産業 } \\
\text { 学働省 }\end{array}$ & 12 & $\begin{array}{l}233,775 \\
(20,547)\end{array}$ & 286,737 \\
\hline $\begin{array}{l}\text { 6. 自然環境の管理及び保全に関する } \\
\text { 基礎的技術開発のための総合研究 }\end{array}$ & $\begin{array}{l}\text { 文部省, 農林水産省, 建設省, } \\
\text { 環境庁 }\end{array}$ & $\begin{array}{c}9 \\
(2)\end{array}$ & $\begin{array}{l}249,097 \\
(78,609)\end{array}$ & $\begin{array}{l}237,510 \\
(57,493)\end{array}$ \\
\hline $\begin{array}{l}\text { 7. 環境污染の生物に与云える慢性影響 } \\
\text { の解明に関する総合研究 }\end{array}$ & $\begin{array}{l}\text { 文部省, 厚生省, 労働省, 環 } \\
\text { 境庁 }\end{array}$ & 10 & 130,764 & 133,304 \\
\hline $\begin{array}{l}\text { 8. 都市における環境保全計画手法の } \\
\text { 開発に関する総合研究 }\end{array}$ & 警察庁, 厚生省, 建設省 & 3 & 79,068 & 64,836 \\
\hline $\begin{array}{l}\text { 9. 騒音・振動の防止及び評価に関す } \\
\text { る総合研究 }\end{array}$ & $\begin{array}{l}\text { 科学技術䒚, 㕌生省, 通商産業 } \\
\text { 省, 運輸省, 学働自設自 }\end{array}$ & 10 & 296,602 & 227,309 \\
\hline $\begin{array}{l}\text { 10. 環境污染物質に係る計測技術の高 } \\
\text { 度化に関する合研究 }\end{array}$ & $\begin{array}{l}\text { 厚生省, 通商産業省, 運輸省, } \\
\text { 郵政, 労働省 }\end{array}$ & $\begin{array}{l}21 \\
(2)\end{array}$ & $\begin{array}{l}490,629 \\
(211,894)\end{array}$ & $\begin{array}{l}471,250 \\
(143,741)\end{array}$ \\
\hline 計 & & $\begin{array}{l}115 \\
(5)\end{array}$ & $\begin{array}{l}3,180,971 \\
(377,448)\end{array}$ & $\begin{array}{l}3,172,891 \\
(221,805)\end{array}$ \\
\hline その 他 の 課 題 & & 2 & 67,472 & 75,552 \\
\hline 計 & & 117 & $3,248,443$ & $3,248,443$ \\
\hline
\end{tabular}

倫考（）内は再掲分を示し外数である.

表 3 昭和 56 年度国立機関公害防止等試験研究費（一括計上）一覧表

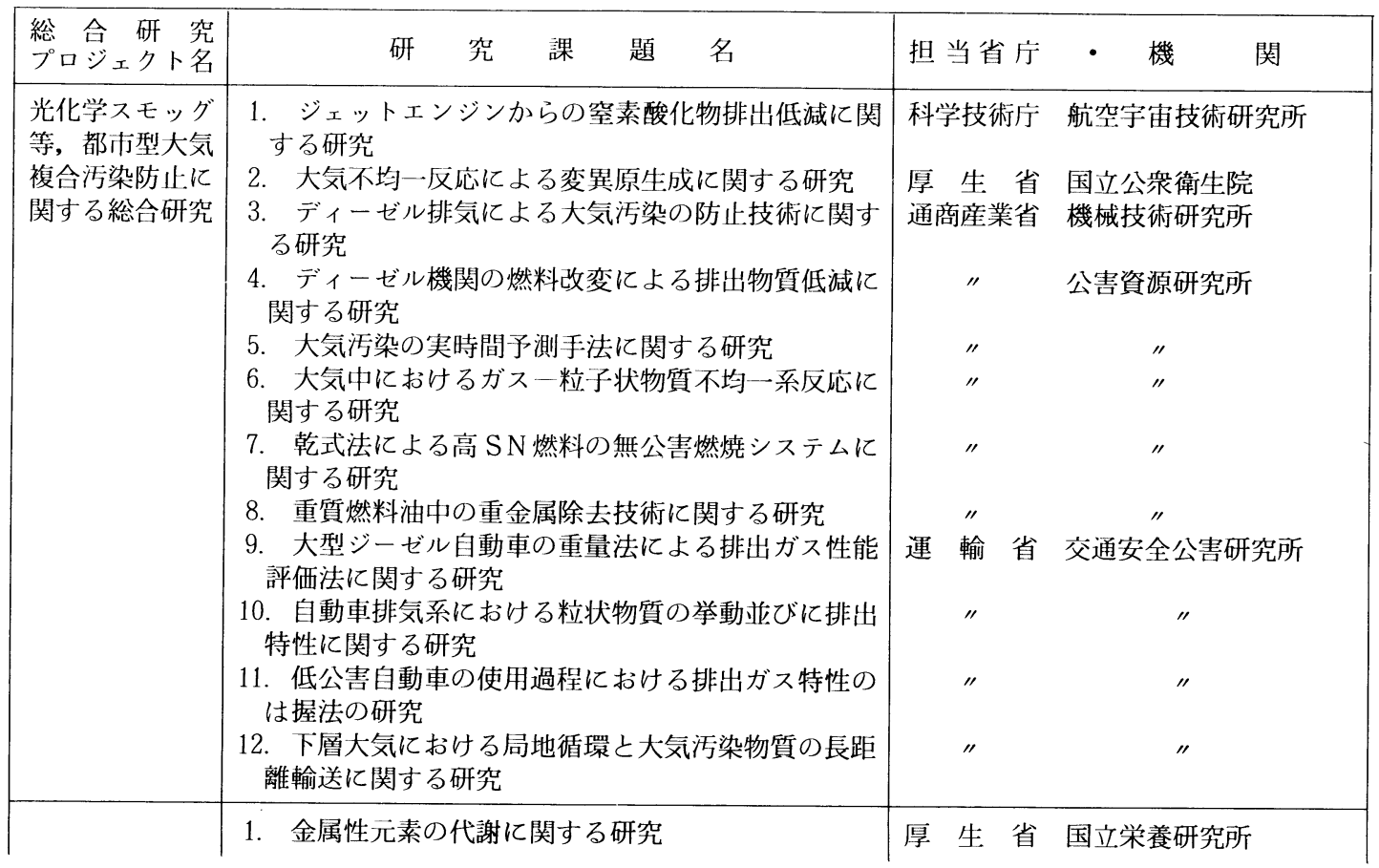




\begin{tabular}{|c|c|c|c|}
\hline $\begin{array}{l}\text { PCB等新污染 } \\
\text { 物質の評価並び } \\
\text { に污染防止に関 } \\
\text { する総合研究 }\end{array}$ & $\begin{array}{l}\text { 2. 人工水棲生態系における環境污染物質の動態に関 } \\
\text { する研究 } \\
\text { 3. 環境污染化学物質の変異原性並びにその試験法の } \\
\text { 開発に関する研究 } \\
\text { *4. 低沸点性有機塩素化合物の生態影響に関する研究 } \\
\text { 5. 有機塩素系農薬をモデルとした化学物質の安全性 } \\
\text { 評価法の開発に関する研究 } \\
\text { 6. 化学物質による人体污染のモニタリング方式の確 } \\
\text { 立と経年推移に関する研究 } \\
\text { (7) 污染レベルを前提とする環境化学物質の安全性試 } \\
\text { 験に関する研究 } \\
\text { 8) アミン系及びアザへテロ環系環境癌原性物質の微 } \\
\text { 量検索法に関する研究 } \\
\text { (9) 生物質を指示剂とする環境污染物質の監視システ } \\
\text { ムに関する研究 }\end{array}$ & 厚 生 省 & $\begin{array}{c}\text { 国立衛生試験所 } \\
\qquad " \\
\qquad " \\
\text { 環境衛生局 } \\
\text { 国立公衆衛生院 } \\
\text { 国立衛生試験所他 } \\
\text { 国立公衆衛生院 } \\
\text { 国立衛生試験所 }\end{array}$ \\
\hline $\begin{array}{l}\text { 排水処理の高度 } \\
\text { 化に関する総合 } \\
\text { 研究 }\end{array}$ & 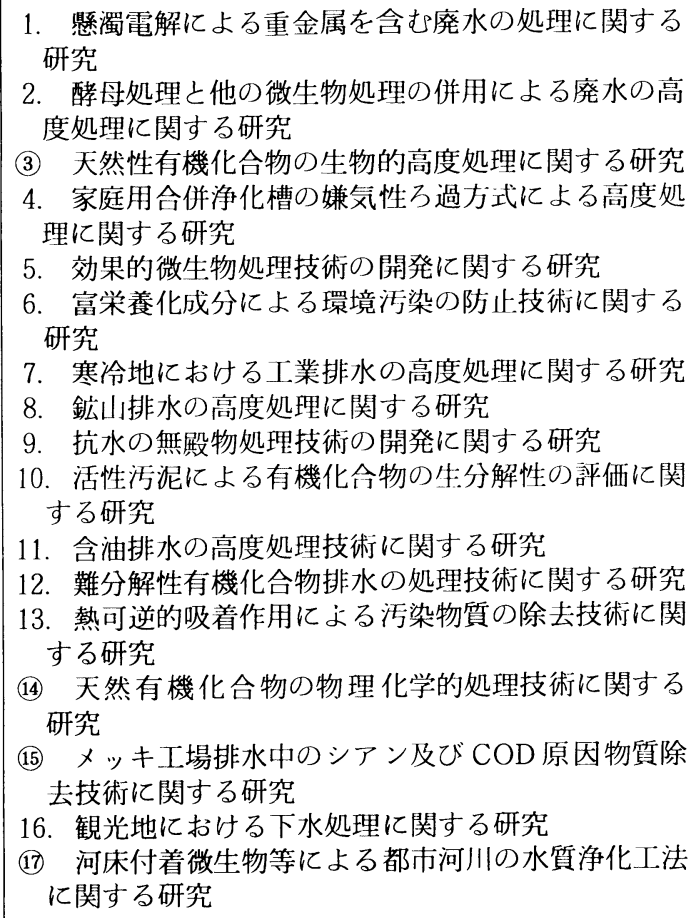 & $\begin{array}{c}\text { 科学技術庁 } \\
\text { 大蔵省 } \\
\text { "厚生 省 } \\
\text { 通商産業省 } \\
\text { " } \\
\text { " } \\
\text { " } \\
\text { " } \\
\text { " } \\
\text { " } \\
\text { " }\end{array}$ & $\begin{array}{l}\text { 金属材料技術研究所 } \\
\text { 釀造試験所 } \\
\text { " } \\
\text { 環境衛生局 } \\
\text { 微生物工業技術研究所 } \\
\text { 化学技術研究所他 } \\
\text { 北海道工業開発試験所 } \\
\text { 公害資源研究所 } \\
\text { 東北工業技術試験所 } \\
\text { 公害資源研究所 } \\
\text { 化学技術研究所 } \\
\text { 大阪工業技術試験所 } \\
\text { 緎維高分子材料研究所 } \\
\text { 公害資源研究所 } \\
\text { 九州工業技術試験所 } \\
\text { 土木研究所 } \\
\text { " }\end{array}$ \\
\hline $\begin{array}{l}\text { 瀬戸内海等沿岸 } \\
\text { 海域の污染防止 } \\
\text { に関する総合研 } \\
\text { 究 }\end{array}$ & $\begin{array}{l}\text { 1. 内湾底泥をめぐる物質収支の動態解明に関する } \\
\text { 研究 } \\
\text { 2. 大規模赤潮の形成及び赤潮被害抑止に関する研究 } \\
\text { 3. 生態系数理モデルによる工場排水の影響予測手法 } \\
\text { に関する研究 } \\
\text { 4. 赤潮による底質污染機構に関する研究 } \\
\text { 5. 瀬戸内海污染底質からの二次污染に関する研究 } \\
\text { 6. 海域の広域長期的污染予測法に関する研究 } \\
\text { 7. 海岸水域の底質污染と浄化に関する研究 } \\
\text { 8. 海中の懸濁物質の高速度計測技術に関する研究 } \\
\text { 9. 瀬戸内海に打る海水交換性及び負荷量影響度の } \\
\text { 研究 } \\
\text { 10. イナートガスシステムからの排出水の実態及び処 } \\
\text { 理方式の研究 } \\
\text { (11) 大量流出油の拡散防止の研究 } \\
\text { 12) 高粘度原油を輸送するタンカーの船外排出油量の } \\
\text { 低減に関する研究 } \\
\text { (13) 生態系物質循環モデルによる港湾海域浄化工法の } \\
\text { 開発に関する研究 }\end{array}$ & $\begin{array}{l}\text { " } \\
\text { " } \\
\text { " } \\
\text { " } \\
\text { " } \\
\text { 輸 省 } \\
\text { " } \\
\text { " }\end{array}$ & $\begin{array}{l}\text { 東海区水産研究所他 } \\
\qquad \text { " } \\
\text { 公害資源研究所 } \\
\text { 地質調査所 } \\
\text { 中国工業技術試験所 } \\
\text { 公害資源研究所 } \\
\text { 名古屋工業技術試験所 } \\
\text { 電子技術総合研究所 } \\
\text { 中国工業技術試験所 } \\
\text { 船舶技術研究所 } \\
\text { " } \\
\text { " }\end{array}$ \\
\hline
\end{tabular}


廃棄物の処理之 資源化技術に関 する総合研究

自然環境の管理 及び保全に関す る基礎的技術開 発のための総合 研究
1. し尿処理施設による污濁負荷の削減に関する研究

(2) 窒素酸化物及び残渣低減のためのでみ安定燃焼技 術関する研究

(3) 有機性污泥の環境保全的評価及び農林業への利用 に関する研究

4. 難分解性廃棄物の微生物処理と再利用に関する 研究

5. スラッジの高度処理技術に関する研究

6. 排煙脱硫石乙うの処理及び利用技術に関する研究

7. 超微粒粉じんの粗粒化再利用技術に関する研究

(8) 石炭灰の浸出処理技術に関する研究

(9) 石炭燃焼過程におりる残渣の活性化処理技術に関 する研究

(10) 石炭灰の固化による有効利用技術に関する研究

11. 一ドロの埋立処理に関する研究

12. 水熱反応による高濃度廃液の無害化処理に関する 研究

1. 広域的森林の動態とその管理に関する統計的研究

*2. 人工水棲生態系に抢ける環境污染物質の動態関 する研究

*3. 内湾底泥をめぐる物質収支の動態解明飞関する研究

4. 光化学オキシダントの農林作物の生育収量に及ほ す影響の解析に関する研究

5. 有機合成（有機りん）殺虫剂の環境生物に及ぼす 影響と代替技術としての害虫誘引物質の開発利用に 関する研究

6. 耕地生態系における水質保全に関する研究

7. 環境変化に対応した海岸林の環境保全機能の維持 強化技術の確立汇関する研究

8. 土㙵一植物一家畜系に抢ける微量元素の動態解明 亿関する研究

(9) 森林食害発生機構の解明及び被害抑止技術に関す 万研究

(10) 写真図による植生モニタリング技術の開発に関す 万研究

11. 森林環境の変化と大型野性動物の生息動態に関す 万基礎的研究

1. 環境污染が動植物の耐性及び種社会に及ぼす遺伝 的影響记関する研究
環境污染の生物 に与える慢性影 響の解明に関す る総合研究

2. 低沸点性有機塩素化合物の生態影響に関する研究

3. 有機重金属の生体への蓄積とその排せつ促進因子 に関する研究

4. 有害重金属の慢性毒性増幅因子乙とに低栄養, 生 体リズム擋乱, 加秢, 騒音, 環境温度に関する研究 5. 環境污染物質によるアレルギー発症機構と生体免 疫機構に及ぼす影響に関する研究

6. 環境污染地に扔ける昆虫類の群集的及び系統的変 化に関する研究

7. 感染並びに免疫応答に及ぼす環境污染物質の影響 に関する研究

8. 多成分系環境污染物質の生態影響の評価法に関す る研究

9. 難溶性有害物質の培養細胞による毒性評価法に関 する研究

10. 微量污染物質の水生生物に与える慢性障害評価法 の開発に関する研究

都市における環 境保全計画手法 の開発に関する
1. 道路交通公害防止のための交通制御論理に関する 研究

（2）都市廃棄物による環境負荷低減化方策の地域計画 厚 生 省 環境衛生局
厚 生 省 国立公衆衛生院 環境衛生局

\section{農林水産省 農業技術研究所他}

通商産業省 微生物工業技術研究所

" 公害資源研究所

" 九州工業技術試験所

" "

" 名古屋工業技術試験所他

" 北海道工業技術試験所

11化学技術研究所他

運 輸 省 港湾技術研究所

労 働 省 産業安全研究所

\section{文 部 省 統計数理研究所}

厚 生 省 国立衛生試験所

農林水産省 東海区水産研究所他 農林技術研究所他

建 設 省 国土地理院

環 境 庁 自然保護局

文 部 省 国立遺伝学研究所

厚 生 省 国立衛生試験所 国立栄養研究所

国立予防衛生研究所

労 働 省 産業医学総合研究所

環 境 庁 企画調整局

警 察 庁 科学警察研究所 


\begin{tabular}{|c|c|c|c|}
\hline 総合研究 & $\begin{array}{l}\text { への適合化に関する研究 } \\
\text { 3. 都市における地区環境の評価に関する研究 }\end{array}$ & 建＼cjkstart設 & 建築研究所 \\
\hline $\begin{array}{l}\text { 騒音・振動の防 } \\
\text { 止及び評価に関 } \\
\text { する総合研究 }\end{array}$ & $\begin{array}{l}\text { 1. ジェットエンジン排出側騷音の低減化に関する研究 } \\
\text { 2. 騒音と振動の複合影響に関する生理学的・心理学 } \\
\text { 的研究 } \\
\text { 3. 精神身体に与える騷音公害の阻害的影響に関する } \\
\text { 研究 } \\
\text { 4. 低周波空気振動の心理, 生理的計測に関する研究 } \\
\text { 5. 騒音の積分効果の評価法に関する研究 } \\
\text { 6. 地盤境界を伝搬する騒音の特性に関する研究 } \\
\text { 7. 実走行状態と等価な単純走行モデルによる自動車 } \\
\text { 騒音の測定法に関する研究 } \\
\text { 8. 過度振動の生体影響に関する研究 } \\
\text { 9. 道路橋からの低周波空気振動の防止に関する研究 } \\
\text { 10 等価騒音レベルを用いた建設騒音に関する研究 }\end{array}$ & $\begin{array}{l}\text { 科学技術庁 } \\
\text { 厚 生 省 } \\
\text { " 通商産業省 } \\
\text { " } \\
\text { "運 輸 香 } \\
\text { 労働 省 } \\
\text { 建設 省 }\end{array}$ & $\begin{array}{l}\text { 航空宇宙技術研究所 } \\
\text { 国立公衆衛生院 } \\
\text { 国立精神衛生研究所 } \\
\text { 製品科学研究所 } \\
\text { 電子技術総合研究所 } \\
\text { 公害資源研究所 } \\
\text { 交通安全研究所 } \\
\text { 産業医学総合研究所 } \\
\text { 土木研究所 } \\
\text { " }\end{array}$ \\
\hline $\begin{array}{l}\text { 環境污染物質に } \\
\text { 係る計測技術の } \\
\text { 高度化に関する } \\
\text { 総合研究 }\end{array}$ & 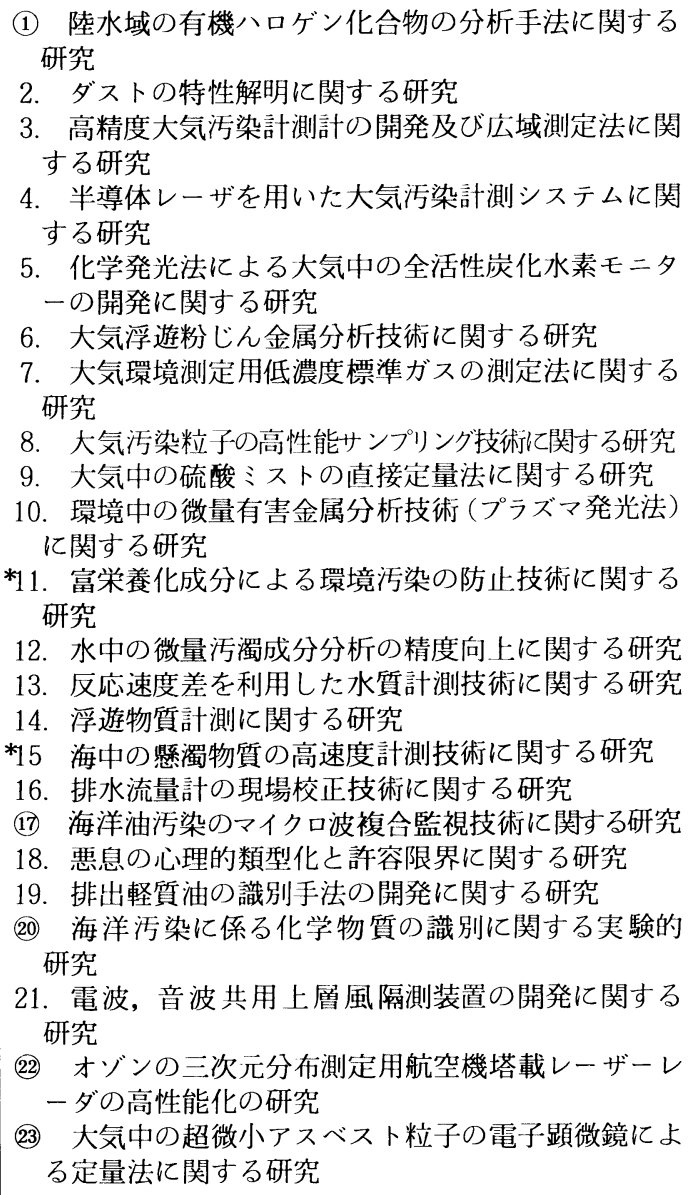 & 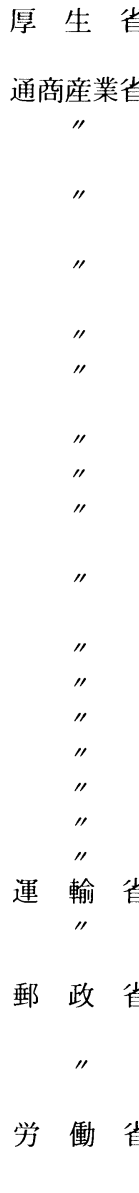 & 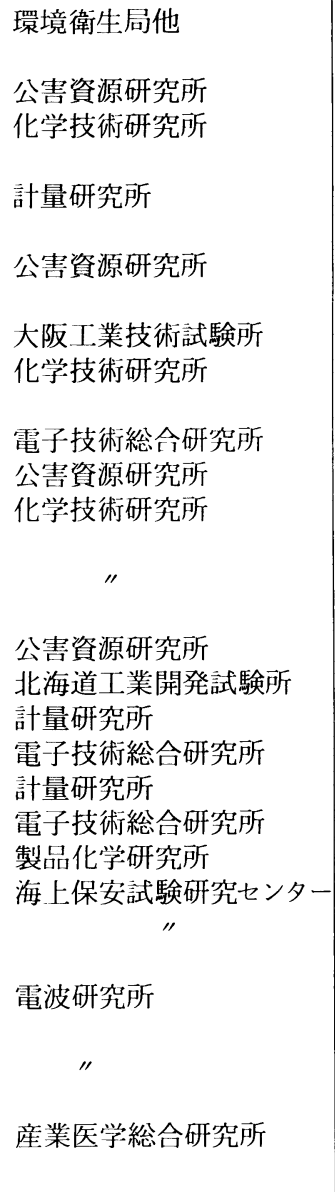 \\
\hline その他の課題 & $\begin{array}{l}\text { 1. 公共用水域における有機塩素化合物の発生メカ二 } \\
\text { ズムとその除去に関する研究 } \\
\text { 2. 湖沼堆積物の調查技術に関する研究 }\end{array}$ & $\begin{array}{l}\text { 厚生 省 } \\
\text { 通商産業笡 }\end{array}$ & $\begin{array}{l}\text { 環境衛生局 } \\
\text { 地質調查所 }\end{array}$ \\
\hline
\end{tabular}

（備考）1. 環境庁調へ

2. * 印の研究課題は, 2 つの総合研究プロジェクトにまたがるあのである.

3. 課題番号の○印は, 56 年度新規課題を示す. 
排水処理の高度化に関する研究を推進する.

昭和 56 年度においては, (1) 天然有機化合物・合成 有機化合物排水及び含油排水の高度処理技術の開発,

(2) 有機態りんを処理するための凝集剤・吸着剤の開 発, (3) 富栄養化成分の効摔的微生物処理技術の開発, (4) 食品工業廃水の中小規模高度処理技術の開発, (5) 鉱山排水の高率的高度処理システムの確立などについ て, 13課題を引き続き実施するほか, 新規課題として, 「天然性有機化合物の生物的高度処理に関する研究」, 「天然有機化合物の物理化学的処理技術に関する研 究」,「メッキ工場排水中のシアン及び COD 原因物質 除去技術に関する研究」及び「河床付着微生物等によ る都市河川の水質浄化工法に関する研究」を実施する こととしている.

\section{2.4 瀬戸内海等沿岸海域の污染防止に関する総合} 研究

我が国の沿岸海域は, 産業排水, 生活排水の増大及 び船舶からの排出油等による水質の污濁が問題となっ ている．なかでも瀬戸内海，東京湾，伊勢湾等の閉鎖 性海域に抢いてはその污染は著しい。乙の総合研究に おいては，乙れら海域の浄化対策を究明するため，海 洋における污濁現象の解明, 海洋生物に与える影響の 解明, 污濁の監視と制御及び污染浄化技術の開発なよ゙ についての研究を推進する.

昭和 56 年度に沶いては，(1) 広域長期的水質污濁予 測手法の確立, (2) 赤潮発生機構の解明, (3) 排水処 理工程の計測自動管理システムの確立, (4) レーザー レーダーを利用した海中の懸濁物質の高速度計測技術 の開発などについて, 10課題を引き続き実施するほか, 新規課題として「大量流出油の拡散防止の研究」,「高 粘度原油を輸送するタンカーの船外排出油量の低減に 関する研究」及び「生態系物質循環モデルによる港湾 海域浄化工法の開発に関する研究」を実施することと している.

\section{2.5 廃棄物の処理と資源化技術に関する総合研究} 廃棄物の処理は, その質の多様化, 量の増大, 二次 污染の発生及び施設用地確保に問題がある.このため, 適正処理の一層の推進を図るとともに減量化の観点か ら, 廃棄物の有効利用が重要視されている. この総合 研究においては，でみの残椬低減などのための安定燃 焼技術及びへドロの埋立処理技術, 各種スラッジ・排 脱石乙う・高分子廃棄物などの処理利用技術, 有機污 泥の農業利用に関する研究を推進する.

昭和 56 年度においては, (1) ヘドロ及び石炭灰の埋
立処理, (2) し尿, スラッジ等の処理と利用, (3) 難 分解性廃棄物などの処理, (4) 有機污泥の農業利用, (5) でみの燃焼技術について，7課題を引き続き実施 するほか, 新規課題として,「窒素酸化物及び残椬低 減のためのでみ安定燃焼技術に関する研究」，「有機性 污泥の環境保全的評価及び農林業への利用に関する研 究」,「石炭灰の浸出処理技術に関する研究」,「石炭燃 焼過程における残渣の活性化処理技術に関する研究 及び「石炭の固化による有効利用技術に関する研究 を実施するてととしている。

\section{2.6 自然環境の管理及び保全に関する基礎的技術 開発のための総合研究}

自然環境の管理と保全についての基礎的技術の開発 を図るため，乙の総合研究においては，污染物質の使 用や開発行為による環境の悪化が，生物や生態系に与 える生理, 生態的影響及び植物被害の定量化, 污染物 質の生態系内における循環, 蓄積などの解明, 自然生 態系の現況及び変化の調査，監視手法の開発なよ゙を 行う.

昭和 56 年度においては, (1) 環境悪化が生態系に与 える影響の解明，(2) 大気污染による植物被害の定量 化手法の開発，(3) 海域生態系における物質循環機構 の解明, (4) 自然環境の調查・監視手法の開発, (5) 耕 地生態系に打ける水質環境保全機構の解明について, 9 課題を引き続き実施するほか, 新規課題として,「森 林食害発生機構の解明及び被害防止技術に関する研 究」及び「写真図による植生モニタリング技術の開発 に関する研究」を実施するてととしている。

\section{2.7 環境污染の生物に与える慢性影響の解明に関 する総合研究}

比較的高濃度の環境污染物質が生物に与える急性, 亜急性の影響についてはかなり解明されているが，微 量污染物質が生物に与える長期的, 慢性的影響につい ては，末解明に近い。乙のため，乙の総合研究におい ては，実験手法そのものの問題を含め，污染物質や騒 音などが生物に与える慢性的影響指標について，遺伝 影響, 生理影響, 生理遺伝影響, 生態影響, 各種環境 要因と障害発見との関係などの面から，10課題を引き 続き実施する。

\section{2.8 都市における環境保全計画手法の開発に関す る総合研究 \\ 人口の急激な都市集中の結果，都市は無計画に膨張 し, 大気, 水の污染, 交通混雑, 緑地空間の減少亡質 の低下，廃棄物処理の困難化等悪化した状況にある。}


ての総合研究においては, 都市に対する総合的な環境 保全計画作成のため, 都市生活価値を考慮した環境指 標の設定, 都市空間系の配置や維持管理技術, 交通流・ 廃棄物等物質流の制御あるいは都市内循環構造化につ いての研究を推進する.

昭和 56 年度に扔いては, 交通流の制御による環境の 保全及び廃棄物低减システムによる制御に関する課題 を引き続き 2 課題実施するとともに, 新規課題として, 「都市廃棄物による環境負荷低減化方策の地域計画へ の適合化㳊関する研究!を実施することとしている。

\subsection{9 騒音・振動の防止及ひ評価に関する総合研究}

工場機械設備の大型化，新幹線鉄道や，航空機等の 大型高速輪送機関の普及，建設工事の頻繁化亡大型化 等に伴い, 騒音・振動は大きな社会問題となっている. このため、ての総合研究に扔いては, 騒音・振動の発 生源対策技術，伝播防止技術，計測技術，予測評価技 術，人間の心理生理などに及ぼす影響の解明などに関 する研究を推進する。昭和 56 年度においては, (1) ジ エットエンジンの騒音発生機構の解明，(2) 低周波空 気振動の発生機構の解明及び計測法の確立., (3) 温度 公配や風が音厓に及ぼす影響の明確化，(4) 騒育之振 動の複合影響の解明，(5) 間けつ振動が人体に及ぼす 電気生理学的影響の解明などに関する課題を引き続き 9 課題実施するとともに, 新規課題として, 「等価騒音 レベルを用いた建設騒音に関する研究」を実施するて ととしている.

\section{2.10 環境污染物質に係る計測技術の高度化に関す} る総合研究

現行の計測技術を評価改良し，その精度を高めると ともに，選定対象の特性にみあった新たな計測技術を 開発して, 分析値の信頼性の確保を図りつつ, 近住注: 目されてきた立体的な環境計測を行いうる公域計測技 術の開発にも積極的に取り組むなど, 計測技術の高度 化を推進する.

昭和 56 年度においては, (1) 標準物質の作成及び評 価, (2) 排出源に求ける計測手法の評価・改良, (3) ポ イント計測技術の評価・改良・開発，(4) 環境活染物 質の監視・識別手法の開発，(5)広域計測技術の開発 について，18課題を引き続き実施するほか，新規課題 として,「陸水域の有機八ロゲン化合物の分析手法に 関する研究」，「海洋油污染のマイクロ波複合監視技術 に関する研究」,「海洋污染に係る化学物質の識別に関 する実験的研究」,「オゾンの三次元分布測定用航空機 塔載レーザ・レーダの高性能化の研究」及び「大気中
の超微小アスベスト粒子の電子顕微鏡による定量法に 関する研究」を実施するてととしている.

\section{3 国立公害研究所の整備と研究の推進}

国立公害研究所は, 昭和 47 年 3 月の発足以来, 我が 国の環境研究の中心的役割りを果たすべき機関として, 鋭意その整備に努めてきており，研究活動において重 要な機能を発揮する大型事験施設のうち，主要なもの が順次整備され，乙れらの施設等を利用する実験研究 を推進するとともに，乙れと併せて行う野外調查研究 をあ充実させる段階にあり, 組織定負の充実とあいまっ て, 研究活動は一段と本格化する時期を迎えている.

\subsection{1 機構, 定員及び施設の整備}

昭和 56 年度に求いては, 大型実験施設の完成及び研 究活動の活発化に伴い，機構・定員の充实を図ること としている. 組織については，資源エネルギーの開発 利用に伴う環境影響について総命的な解析評価研究を 担当する第 た グルーブを総合解析部に新設するほか， 底質上壌計測研究室, 環境心理研究室及び生物環境管 理研究室を新設するなど，内部機構の允実を四るこよ としている。

定員については，大型宣験施設に関連する研究及び 新規の特別研究の推進体例の虽化在中心に 9 多の增早 を胀るこよとし，て机より，56 作度机は，10部 2 課38室，243名とするてととしている。

また，施設整備については，植物努験棟 II 及び騒音 影響実験棟が光成するほか, 新たに臨湖実験施設, 系 統微牛物維持施設などを建設するとととしている.

\subsection{2 特別研究の推進}

昭和 56 年度に抢いて実施す万特別研究は11課題之

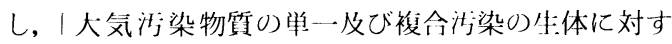
万影響に関する実験的研究!，「臨界地域の気像の特性 之大気拡散琴象の研究」「「海域に打ける简栄飬化之赤 潮の発生機構に関する研究!|, | 環境污染の遠隔計測・ 評価手法の開発に関する研究」など 9 課題を引き続き 奏施するほか，新たに「污泥の土㙥還元とその環境影 響に関する研究」及び｜有害污染物質による水界生態 系の擋乱上回復過程に関する研究!の 2 課題を実施す るとととしている.

さらに, 経常研究としては, 環境活染が人の健康及 び動植物に及ぼす影響, 環境活染の機構の解明, 環境 污染の測定分析方法, 環境に関する知見を活用した総 合解析等の各分野に打りる研究活動を一段と拡充強化 するてととしている。

(文責 寺阔) 